\title{
PERAN PERBANKAN SYARIAH DALAM MEMPENGARUHI PERTUMBUHAN EKONOMI INDONESIA TAHUN 1993-20161
}

\author{
Annisa Nurhasibah \\ Departemen Ekonomi Syariah - Fakultas Ekonomi dan Bisnis - Universitas Airlangga \\ Email: annisanurhasibah4@gmail.com \\ Raditya Sukmana \\ Departemen Ekonomi Syariah - Fakultas Ekonomi dan Bisnis - Universitas Airlangga \\ Email: raditya-s@feb.unair.ac.id
}

\begin{abstract}
:
This study aims to determine the influence of Islamic banking, and investment on economic growth Indonesia in 1993-2016. This study uses a quantitative approach. The analysis technique used Autoregressive Distributed Lags (ARDL). This research used simple random sample. Sample that used in this research were taken from World Bank Data while for islamic banking data obtained from official website of all islamic banking in Indonesia. The result of the research shows that in the long term Islamic financing variable has a significant positive impact on the economic growth in Indonesia, while the short variable of sharia banking has a significant positive impact on the economic growth in Indonesia. Both of these proves that sharia banking has an active role to the economic growth of the country, especially in Indonesia. While the investment variables derived into variable Gross Fixed Capital Formation or GFCF have a significant negative impact on the economic growth of Indonesia in the short and long term.
\end{abstract}

Keyword : Islamic Banking, Investment, Economic Growth, Indonesia, ARDL

\section{PENDAHULUAN}

Pertumbuhan ekonomi merupakan masalah perekonomian suatu negara dalam jangka panjang selama periode tertentu dan dapat dikaitkan juga sebagai kenaikan kapasitas produksi suatu perekonomian yang diwujudkan dalam bentuk kenaikan pendapatan nasional. Adanya pertumbuhan ekonomi merupakan indikasi keberhasilan permbangunan ekonomi. Dalam analisis makro pertumbuhan ekonomi yang dicapai suatu negara dapat diukur dari perimbangan pendapatan nasional riil yang dicapai oleh suatu negara (Ernita, 2013).
Pertumbuhan ekonomi juga merupakan sebuah ukuran paling presisi dalam mengukur output total sebuah negara. Pertumbuhan ekonomi dapat dihitung melalui Product Domestic Bruto (Sukirno, 2013). Hingga saat ini, pertumbuhan ekonomi masih menjadi tolak ukur paling penting di dunia dalam menentukan kesuksesan perekonomian suatu negara.

Perekonomian Indonesia pada triwulan I tahun 2017 tumbuh sebesar 5,0 persen, sedikit lebih tinggi dibandingkan triwulan IV tahun 2016 yang tumbuh sebesar 4,9 persen. Pertumbuhan tersebut dipengaruhi oleh membaiknya kondisi perekonomian global walaupun

\footnotetext{
${ }^{1}$ Jurnal ini merupakan bagian dari skripsi Annisa Nurhasibah, NIM: 041511433082 , yang diuji pada tanggal 25 Juni 2019.
} 
pertumbuhannya belum merata. Dari sisi domestik, kinerja pertumbuhan ekonomi didorong oleh membaiknya ekspor dan permintaan domestik (Bappenas, 2017).

Indonesia merupakan negara dengan sistem keuangan yang bankbased industry. Bank-based industry adalah sistem keuangan yang di dominasi oleh pasar perbankan (Taqwa, 2017). Pendukung sistem keuangan bank-based mengatakan kalau sistem ini lebih baik daripada market-based dalam mengatasi terjadinya asimetri informasi terutama untuk negara-negara yang berada dalam tahapan awal pembangunan ekonominya. Tanpa adanya bank, biaya yang harus dilkeluarkan investor untuk memperoleh dan memproses informasi mengenai kondisi dan kinerja perusahaan menjadi sangat tinggi. Keberadaan bank menurunkan risiko dan biaya pengawasan yang harus ditanggung investor publik. Pengawasan oleh bank sebagai kreditur jauh lebih efektif daripada pengawasan oleh sekumpulan kas surplus (investor) dengan informasi terbatas yang dimilikinya (Frensindy, 2007).

Otoritas Jasa Keuangan (2013) menyatakan bahwa Bank Umum Syariah (BUS), Unit Usaha Syariah (UUS) dan Bank Pembiayaan Rakyat Syariah (BPRS) memiliki aset sebesar 248,1 triliun rupiah pada tahun 2013 atau tumbuh sebesar $24,2 \%$. Pertumbuhan aset perbankan syariah lebih besar jika dibandingkan dengan pertumbuhan total aset perbankan, sehingga market share perbankan syariah secara keseluruhan meningkat dari $4,61 \%$ menjadi $4,93 \%$.

Selain perbankan syariah, faktor pendorong pertumbuhan ekonomi adalah perdagangan internasional dan investasi. Menurut Sutawijaya (2010)investasi memegang peran penting dalam kegiatan perekonomian suatu negara. Sedangkan ekspor menghasilkan devisa yang akan digunakan untuk membiayai impor bahan baku dan barang modal yang diperlukan dalam proses produksi yang akan membentuk nilai tambah. Agregasi nilai tambah yang dihasilkan oleh seluruh unit produksi dalam perekonomian merupakan nilai Produk Domestik Bruto. Investasi atau penanaman modal adalah pembelian barang modal pelengkapan produksi untuk menambah kemampuan memproduksi barangbarang dan jasa yang dibutuhkan dalam perekonomian. Oleh karena itu, tingkat pertumbuhan ekonomi yang tinggi dan berkesinambungan pada umumnya didukung oleh peningkatan investasi.

Penelitian ini akan menganalisis pengaruh perbankan syariah, dan investasi, terhadap pertumbuhan ekonomi. Kinerja keuangan syariah di representasikan dengan total pembiayaan Bank Umum Syariah di Indonesiatanpa memasukkan total pembiayaan pada Industri Keuangan Non Bank Syariah (IKNB) dalam analisis. Untuk menggambarkan kondisi di sektor riil, penelitian ini menggunakan Gross Fixed Capital Formation (GFCF). Ketersediaan 
data mulai dari tahun 1993 hingga 2016 akan menambah relevansi dalam pengaruh jangka pendek maupun jangka panjang.

\section{Rumusan Masalah}

Berdasarkan latar belakang yang telah diuraikan diatas, maka rumusan masalah pada penelitian ini adalah apakah terdapat pengaruh pembiayaan perbankan syariah, Gross Fixed Capital Formation terhadap produk domestik bruto di Indonesia tahun 1993-2016.

\section{Tujuan Penelitian}

Tujuan penelitian ini adalah untuk mengetahui pengaruh pembiayaan perbankan syariahdan Gross Fixed Capital Formation terhadap produk domestik bruto di Indonesia tahun 1993-2016.

\section{LANDASAN TEORI}

\section{Perbankan Syariah}

Menurut Undang-undang No. 10 tahun 1998 tentang perubahan Undang undang No.7 tahun 1992 tentang perbankan, Bank adalah badan usaha yang menghimpun dana dari masyarakat dalam bentuk simpanan dan menyalurkannya kepada masyarakat dalam bentuk kredit dan/atau bentubentuk lainnya dalam rangka meningkatkan taraf hidup rakyat banyak. Sedangkan menurut Sudarsono (2003), yang dimaksud dengan bank syariah adalah lembaga kevangan yang usaha pokoknya memberikan kredit dan jasajasa lain dalam lalu lintas pembayaran serta peredaran vang yang beroperasi disesuaikan dengan prinsip - prinsip syariah.

\section{Pembiayaan Pada Perbankan Syariah}

Menurut

Undang-undang

Perbankan No. 10 Tahun 1998, Pembiayaan adalah penyediaan vang atau tagihan yang dapat dibersamakan dengan itu, berdasarkan persetujuan atau kesepakatan antara bank dan pihak lain yang dibiayai untuk mengembalikan vang atau tagihan tersebut setelah jangka waktu tertentu dengan imbalan atau bagi hasil (Ismail, 2010).

\section{Teori Investasi}

Menurut Noor (2009), investasi adalah kegiatan mengalokasikan atau menanamkan sumberdaya (resources) saat ini (sekarang) dengan harapan mendapatkan manfaat dikemudian hari (masa datang). Untuk memudahkan pengertian dan perhitungan, maka sumberdaya (resources) ini biasanya diterjemahkan (dikonversi) kedalam satuan moneter atau vang. Menanamkan vang sekarang, berarti uang tersebut yang seharusnya dapat dikonsumsi, namun karena kegiatan investasi, uang tersebut dialihkan untuk ditanamkan bagi keuntungan masa depan. Investasi memiliki 2 (dua) aspek, yaitu : konsumsi saat ini, dan harapan dapat keuntungan dimasa datang.

\section{Konsep Pertumbuhan Ekonomi}

Sukirno (2010) mengemukakan bahwa pertumbuhan ekonomi adalah perkembangan fiskal produksi barang dan jasa yang berlaku di suatu negara, seperti 
pertambahan dan jumlah produksi barang industri, perkembangan infrastruktur, pertambahan jumlah sekolah, pertambahan produksi sektor jasa, dan pertambahan produksi barang modal.

Terdapat tiga faktor utama dalam pertumbuhan ekonomi dari setiap bangsa, yaitu akumulasi modal, yang meliputi semua bentuk atau jenis investasi baru yang ditanamkan pada tanah, peralatan fisik, dan modal atau sumberdaya manusia, pertumbuhan penduduk, yang pada akhirnya akan memperbanyak jumlah angkatan kerja, dan kemajuan teknologi. Akumulasi modal terjadi apabila sebagian dari pendapatan ditabung dan diinvestasikan kembali dengan tujuan memperbesar output dan pendapatan dikemudian hari. Selain investasi dalam modal fisik, investasi dalam pembinaan sumberdaya manusia juga dapat meningkatkan kualitas modal manusia, sehingga pada akhirnya akan membawa dampak positif terhadap angka produksi, bahkan akan lebih besar lagi mengingat terus bertambahnya jumlah manusia (Alhumaira, 2017).

Dornbuch dalam bukunya yang berjudul Makroekonomi menyatakan bahwa tingkat pertumbuhan dari perekonomian adalah tingkat dimana produk domestik bruto (PDB) meningkat. Secara rata-rata, kebanyakan perekonomian tumbuh beberapa poin prosentase per tahun selama beberapa periode yang panjang. Hal ini disebabkan oleh perubahan PDB adalah tersedianya

sejumlah sumber daya sejalan dengan perubahan perekonomian. Yang dimaksud dengan sumber daya adalah modal dan angkatan kerja. Angkatan kerja adalah orang yang sedang atau tengah mencari pekerjaan, tumbuh sepanjang waktu dan menyediakan satu sumber untuk meningkatkan produksi. Persediaan modal, termasuk gedunggedung dan mesin, meningkat pula sepanjang waktu, menyediakan sumber lain untuk mengingkatkan output. Kenaikan persediaan faktor produksi (tenaga kerja dan modal) yang digunakan untuk memproduksi barang danjasa merupakan bagian dari kenaikan PDB.

Hubungan Pembiayaan Perbankan Syariah Terhadap Pertumbuhan Ekonomi

Fahrani (2013) menyatakan bahwa terdapat korelasi antara pembiayaan perbankan syariah dengan pertumbuhan ekonomi dalam jangka panjang ataupun jangka pendek. Pernyataan ini juga diperkuat dengan Abduh (2012), dimana terdapat hubungan kausisalitas dua arah antara pembiayaan perbankan syariah dengan pertumbuhan ekonomi.

Hubungan Investasi
Pertumbuhan Ekonomi
Samuelson (1992) investasi
merupakan komponen pengeluaran yang
cukup besar dan dapat berubah-ubah,
perubahan investasi yang cukup besar
dapat mempengaruhi permintaan
agregat dan selanjutnya berpengaruh
terhadap output serta kesempatan kerja.


Selanjutnya investasi merupakan akumulasi modal, dengan pembangunan sejumlah bangunan serta pengadaan peralatan yang berguna, maka output potensial suatu bangsa akan bertambah dan pertumbuhan ekonomi akan meningkat dalam jangka panjang. Karena itu investasi memainkan peran penting, yaitu penentuan jumlah output serta pendapatan. Sedangkan menurut Digdowiseiso (2009) pengaruh investasi terhadap pendapatan nasional adalah positif. Apabila pendapatan nasional meningkat maka pertumbuhan ekonomi juga meningkat karena pendapatan nasional merupakan indikator pertumbuhan ekonomi dari sisi pendapatan.

\section{Model Analisis}

Formulasi model yang digunakan adalah sebagai berikut :

$$
Y=\alpha_{0}+\alpha_{1} X_{1}+\alpha_{2} X_{2}+e t
$$

Dimana :

$Y=$ Produk Domestik Bruto

$X_{1}=$ Total Pembiayaan Perbankan Syariah

$\mathrm{X}_{2}=$ Gross Fixed Capital Formation

$a_{0}=$ intersep

$a_{1}, a_{2}, a_{3}=$ koefisien variabel

et= nilai error

\section{METODE PENELITIAN}

\section{Pendekatan penelitian}

Pendekatan yang digunakan pada penelitian ini adalah pendekatan kuantitatif.

\section{Identifikasi variable}

Berdasarkan rumusan masalah penelitian, maka variabel endogen dalam penelitian ini adalah pertumbuhan ekonomidan variable eksogen adalah perbankan syariah, investaso, dan perdagangan internasional.

\section{Definisi operasional}

1. Pertumbuhan Ekonomi

Untuk mendapatkan ukuran presisi dari PDB, penelitian ini menggunakan data nilai konstan dengan tahun dasar 2010. Menurut BI (2016) PDB dengan harga konstan menunjukkan nilai tambah barang dan jasa yang dihitung menggukan harga yang berlaku pada satu tahun tertentu sebagai tahun dasar. PDB konstan digunakan untuk mengetahui kemampuan sumber daya dalam mendorong pertumbuhan ekonomi secarariil dari tahun ke tahun atau pertumbuhan ekonomi yang tidak dipengaruhi oleh faktor harga.

2. Perbankan Syariah

Penelitian ini menggunakan total pembiayaan pada bank umum syariah dan tidak menggunakan data pada unit usaha syariah.

3. Investasi

Jenis investasi yang digunakan dalam penelitian ini adalah Gross Fixed Capital Formation (GFCF) karena GFCF merupakan komponen pembentukan Gross Domestic Product (GDP). Data yang digunakan berupa data konstan tahun 1993-2016. 
Jenis dan sumber data

Penelitian ini menggunakan metode sampel acak sederhana, dana didapatkan dari World Bank Data sedangkan untuk data perbankan syariah didapat dari website resmi seluruh perbankan syariah di Indonesia.

\section{Populasi dan sampel}

Populasi dalam penelitian ini adalah nilai Produk Domestik Bruto (PDB), total pembiayaan perbankan syariah, dan total investasipada seluruh negara di dunia.Sedangkan dalam panelitian ini tidak terdapat metode pemilihan sampel.

\section{Teknik analisis}

Peneliti menggunakan teknik analisa data dengan menggunakan model Autoregressive Distributed Lags (ARDL) dengan menggunakan softwere Eviews versi 9.5 pada keseluruhan data untuk menguki hipotesis hubungan dinamis long-run dan short-run antar variabel. Sebagaimana dinyatakan oleh Pesaran dan Shin (1999) bahwa pendekatan model ARDL seringkali digunakan dalam ekonometrika karena metode tersebut memeriksa hubungan jangka panjang dan kointegrasi antar variabel. ARDL merupakan Least Square Resgressions standar yang menyatakan lag dari masing-masing variabel terikat dan bebsar sebagai regressors.

\section{HASIL DAN PEMBAHASAN}

Hasil Pengujian Stasionaritas Data (Unit Root Test)

Penelitian ini menggunakan tiga jenis uji stasionaritas data agar mendapatkan hasil yang maksimal, uji tersebut adalah Augmented Dickey Fuller Test (ADF). Hasil pengujian akar unit pada tingkat level ditunjukkan oleh tabel 1 sebagai berikut:

Tabel 1.

Hasil Uji Augmented Dickey Fuller Pada Tingkat Level

\begin{tabular}{|l|c|c|c|c|c|c|}
\hline \multirow{2}{*}{ VAR } & \multirow{2}{*}{ T- Stat } & \multirow{2}{*}{ Prob } & \multicolumn{3}{|c|}{ ADF } & \multirow{2}{*}{ KET } \\
\cline { 4 - 5 } & & & $\mathbf{1} \%$ & $\mathbf{5 \%}$ & $\mathbf{1 0 \%}$ & \\
\hline GDP & 1.504791 & 0.9986 & -3.808546 & -3.020686 & -2.650413 & $\begin{array}{c}\text { Tidak } \\
\text { Stasioner }\end{array}$ \\
\hline FIN & -0.136797 & 0.9323 & -3.808546 & -3.020686 & -2.650413 & $\begin{array}{c}\text { Tidak } \\
\text { Stasioner }\end{array}$ \\
\hline GFCF & 0.305088 & 0.9724 & -3.808546 & -3.020686 & -2.650413 & $\begin{array}{c}\text { Tidak } \\
\text { Stasioner }\end{array}$ \\
\hline
\end{tabular}

Pada uji stasionaritas data yang menggunakan uji Augmented Dickey Fuller, data dikatakan stasioner jika nilai TStatistik lebih besar dari nilai signifikasi ADF dan probabilitas kurang dari nilai kritis $a=1 \%, a=5 \%, a=10 \%$. Hasil uji ADF pada penelitian ini menunjukkan bahwa seluruh variabel tidak stasioner pada tingka level, karena seluruh probabilitasnya lebih besar dari nilai kritis $a=1 \%, a=5 \%, a=10 \%$.

Tabel 2.

Hasil Uji Augmented Dickey FullerPada Tingkat First Different

\begin{tabular}{|c|c|c|c|c|c|c|}
\hline \multirow{2}{*}{ VAR } & \multirow{2}{*}{ T- Stat } & \multirow{2}{*}{ Prob } & \multicolumn{3}{|c|}{ ADF } & \multirow{2}{*}{ KET } \\
\cline { 4 - 6 } & & & $\mathbf{1} \%$ & $\mathbf{5} \%$ & $\mathbf{1 0} \%$ & \\
\hline GDP & -3.513041 & 0.0192 & -3.831511 & -3.029970 & -2.655194 & Stasioner \\
\hline FIN & -5.688872 & 0.0002 & -3.808546 & -3.020686 & -2.650413 & Stasioner \\
\hline GFCF & -5.413387 & 0.0003 & -3.808546 & -3.020686 & -2.650413 & Stasioner \\
\hline
\end{tabular}

Hasil dari uji ADF pada tingkat first different menyatakan bahwa seluruh variabel telah stasioner pada tingkat first different, dimana nilai probabilitasnya lebih kecil dari nilai kritis $a=1 \%$ dan $a=5 \%$ serta nilai T-stastistiknya lebih besar dari nilai ADF. 
Hasil Penentuan Lag Optimal

Tabel 3.

\begin{tabular}{ccccccc}
\hline \hline Lag & LogL & LR & FPE & AIC & SC & HQ \\
\hline \hline 0 & -0.189779 & NA & 0.000272 & 0.303788 & 0.453006 & 0.336172 \\
1 & 74.94731 & 121.6505 & $5.07 \mathrm{e}-07$ & -5.994982 & -5.398112 & -5.865446 \\
2 & 101.0810 & $34.84496^{*}$ & $1.06 \mathrm{e}-07$ & -7.626765 & -6.5822242 & -7.4000077 \\
3 & 115.5338 & 15.14103 & $7.48 \mathrm{e}-08^{*}$ & $-8.146079^{*}$ & $-6.653904^{*}$ & $-7.822239^{*}$ \\
\hline \hline
\end{tabular}

Tabel 3 diatas merupakan hasil uji lag optimal yang dilakukan menggunakan eviews 9.5. Berdasarkan hasil tersebut, eviews 9.5 merekomendasikan panjang lag optimal pada lag 3 untuk data yang diambil di Indonesia. Karena tiga dari kriteria penentuan jumlah lag dalam model ARDL menunjukkan tingkat signifikansi pada lag ke-3.

\section{ARDL Bound Testing}

Sebelum melanjutkan ke tahap selanjutnya, penelitian ini harus melakukan Bound Testing. Bound Testing digunakan untuk mengetahui apakah variabel endogen dan eksogen berkointegrasi jangka panjang atau tidak. Apabila nilai FStatistik lebih besar daripada nilai 10 dan II, maka dapat disimpulkan bahwa variabel terkointegrasi jangka panjang. Hasil penelitian ini menunjukkan bahwa nilai FStatistik sebesar 17.15417 sedangkan nilai 10 dan 10 pada tingkat signifikansi 5\% adalah 3.1 dan 3.87. Hal ini menunjukkan bahwa variabel terkointegrasi dalam jangka panjang.

Tabel 4.

\section{ARDL Boud Testing}

\begin{tabular}{lcrrr} 
F-Bounds Test & & \multicolumn{3}{c}{ Null Hypothesis: No levels relationship } \\
\hline \hline Test Statistic & Value & Signif. & $\mathrm{I}(0)$ & $\mathrm{I}(1)$ \\
\hline \hline F-statistic & 17.15417 & $10 \%$ & 2.63 & 3.35 \\
$\mathrm{k}$ & 2 & $5 \%$ & 3.1 & 3.87 \\
& & $2.5 \%$ & 3.55 & 4.38 \\
& & $1 \%$ & 4.13 & 5 \\
\hline \hline
\end{tabular}

Setelah melewati tiga uji diatas, penelitian ini dilanjutkan dengan uji estimasi model. Dimana dalam uji estimasi model terdapat dua hasil uji. Hasil estimasi jangka panjang dan hasil estimasi jangka pendek. Adapun estimasi jangka panjang dan jangka pendek dapat dilihat pada tabel 4.6 Berikut hasil estimasi model ARDL:

Tabel 5.

Hasil Estimasi Model

\begin{tabular}{crrrr}
\hline \hline Variable & Coefficient & Std. Error & t-Statistic & Prob. \\
\hline \hline C & 2.524992 & 0.759662 & 3.323838 & 0.0068 \\
DFIN(-1) & -0.025806 & 0.025696 & -1.004268 & 0.3368 \\
DFIN(-2) & 0.013246 & 0.023399 & 0.566091 & 0.5827 \\
DFIN(-3) & 0.039289 & 0.011043 & 3.557840 & 0.0045 \\
DGFCF(-1) & -0.102074 & 0.120050 & -0.850265 & 0.4133 \\
DGFCF(-2) & -0.176396 & 0.094827 & -1.860195 & 0.0898 \\
DGFCF(-3) & -0.144645 & 0.076147 & -1.899557 & 0.0840 \\
FIN(-1) & 0.056118 & 0.011235 & 4.994859 & 0.0004 \\
GFCF(-1) & -0.236701 & 0.068306 & -3.465293 & 0.0053 \\
\hline \hline R-squared & 0.808556 & Mean dependent var & 0.039468 \\
Adjusted R-squared & 0.669324 & S.D. dependent var & 0.043991 \\
S.E. of regression & 0.025297 & Akaike info criterion & -4.214113 \\
Sum squared resid & 0.007039 & Schwarz criterion & -3.766033 \\
Log likelihood & 51.14113 & Hannan-Quinn criter. & -4.126643 \\
F-statistic & 5.807251 & Durbin-Watson stat & 2.062036 \\
Prob(F-statistic) & 0.004586 & & \\
\hline \hline
\end{tabular}

sebagai berikut:

a. Koefisien variabel FIN menuntukkan nilai positif. Hal ini menandakan bahwa ketika pembiayaan perbankan syariah meningkat sebesar $1 \%$, maka tingkat PDB Indonesia meningkat sebesar $5,6 \%$ dengan asumsi ceteris paribus.

b. Koefisien variabel GFCF menunjukkan nilai negatif. Hal ini menandakan bahwa ketika Gross Fixed Capital Formation (GFCF) meningkat sebesar 1\%, maka tingkat PBD Indonesia mengalami penurunan sebesar $23 \%$.

Hasil estimasi model dalam jangka pendek dapat diidentifikasi sebagai berikut:

a. Variabel FIN pada lag ketiga menunjukkan nilai positif. $\mathrm{Hal}$ ini 
menandakan bahwa apabila pembiayaan perbankan syariah mengalami kenaikan sebesar $1 \%$ maka PBD Indonesia akan mengalami kenaikan $3,9 \%$ pada tahun ketiga dengan asumsi ceteris paribus.

b. Variabel GFCF pada lag kedua dan ketiga menunjukkan nilai negatif. Hal ini menandakan bahwa apabila Gross Fixed Capital Formation (GFCF) mengalami kenaikan sebesar $1 \%$ maka PBD Indonesia akan mengalami penurunan sebesar $17 \%$ pada tahun kedua dan $14 \%$ pada tahun ketiga dengan asumsi ceteris paribus.

Analisis Hasil Penelitian

Pengaruh Perbankan Syariah Terhadap Pertumbuhan Ekonomi Indonesia dalam Jangka Pendek

Perbankan syariah dalam jangka pendek di Indonesia berpengaruh positif terhadap pertumbuhan ekonomi. Koefisien 0,039289 menandakan bahwa pertumbuhan ekonomi akan meningkat sebesar 3,9\% ketika perbankan syariah mengalami kenaikan sebesar $1 \%$. Pembiayaan perbankan syariah merupakan aktivitas peminjaman dana pada sektor riil karena hampir seluruh akadnya bersinggungan dengan usaha/bisnis masyarakat yang pada akhirnya akan meningkatkan output dan kapasitas produksi. Sukirno (2010) menyatakan bahwa pertumbuhan ekonomi ditandai dengan kenaikan jumlah barang dan jasa atau kapasitas produksi di dalam suatu negara. Hal ini membuktikan bahwa perbankan syariah dalam jangka pendek merupakan unsur penting bagi pertumbuhan ekonomi. Penemuan ini juga berhasil dikemukakan oleh Fahrani dan Dastan (2013) serta penelitian yang dilakukan oleh Abduh dan Omar (2012).

Pengaruh Perbankan Syariah Terhadap Pertumbuhan Ekonomi Indonesia dalam Jangka Panjang

Hasil uji estimasi model nenunjukkan bahwa koefisien variabel perbankan syariah yang di proyeksikan dengan variabel FIN bernilai 0,056118. Hal ini menunjukkan bahwa apabila perbankan syariah mengalami peningkatan sebesar 1\%, maka PDB Indonesia juga mengalami peningkatan sebesar $5,6 \%$. Penelitian ini sesuai dengan penelitian yang dilakukan oleh Fahrani dan Dastan (2013) serta penelitian yang dilakukan oleh Abduh dan Omar (2012).

Bank syariah merupakan lembaga perantara keuangan, dimana bank syariah bertugas untuk menghimpun dana dari masyarakat dalam bentuk pembiayaan atau dalam bentuk lainnya dalam rangka meningkatkan taraf hidup masyarakat. Perbankan syariah di Indonesiaberpengaruh positif terhadap pertumbuhan ekonomi sehingga mampu untuk menunjang pelaksanaan pembangunan nasional, dan stabilitas nasional. Hal ini sesuai dengan Firman Allah dalam Al-Qur'an Surat Al-Anbiya' ayat 107, yang artinya sebagai berikut, "Dan tiadalah Kami mengutus kamu, 
melainkan untuk (menjadi) rahmat bagi semesta alam" (Kementerian Agama Rl, 2014). Serta janji Allah dalam menjamin rezeki setiap makhluknya pada Al-Qur'an Surat Hud ayat 6, yang artinya sebagai berikut, "Dan tidak ada suatu binatang melata pun di bumi melainkan Allah-lah yang memberi rezekinya, dan Dia mengetahui tempat berdiam binatang itu dan tempat penyimpanannya. Semuanya tertulis dalam Kitab yang nyata (Lauh mahfuzh)" (Kementerian Agama Rl, 2014). Indonesia merupakan negara yang sedang giat melakukan pembangunan ekonomi. Pembangunan ekonomi haruslah didukung dengan sektor keuangan yang sehat dari perbankan pada umumnya dan perbankan syariah pada khususnya. Hal ini dapat diketahui dari tingkat Finance to Deposit Ration (FDR) bank syariah yang terus berada diatas $80 \%$. Tingkat Finance to Deposit Ration (FDR) merupakan rasio antara pembiayaan yang diberikan dengan total dana pihak ketiga. Tingkat FDR perbankan syariah di Indonesia dapat dilihat dalam grafik berikut:

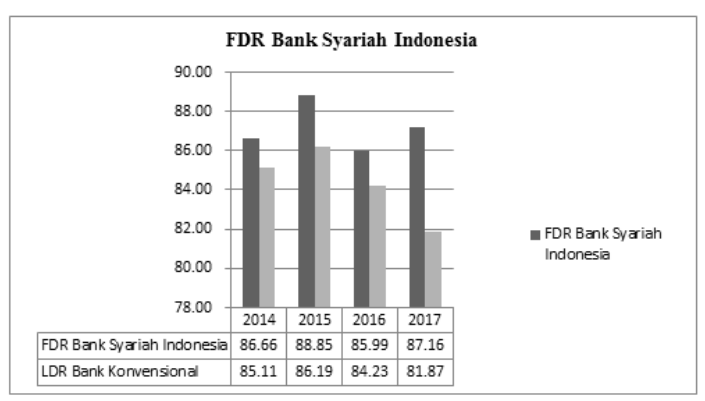

Sumber: Statistik Perbankan Syariah OJK 2016, Data diolah

\section{Gambar 1.}

FDR Bank Syariah Indonesia Tahun 20142017 (dalam Prosentase)

Pengaruh Investasi Terhadap Pertumbuhan Ekonomi Indonesia dalam Jangka Pendek Investasi yang dalam penelitian ini diproyeksikan dengan tingkat Gross Fixed Capital Formation (GFCF) dimana hasil dari penelitian ini menyatakan bahwa GFCF memiliki hubungan negatif dengan pertumbuhan ekonomi. Pernyataan tersebut dibuktikan dengan koefisien estimasi ARDL yang menunjukkan angka 0.176396 dan -0.144645 . Kanu (2014) menyatakan bahwa dengan menggunakan metode OLS dan VAR Gross Fixed Capital Formation (GFCF) juga berdampak signifikan negatif terhadap pertumbuhan ekonomi dalam jangka pendek.

Ketidakefektifan konribusi GFCF terhadap pertumbuhan ekonomi Indonesia diakibatkan oleh tingginya konsumsi rumah tangga yang tidak tepat. Pertumbuhan ekonomi yang didominasi oleh konsumsi rumah tangga menyebabkan kejenuhan masyarakat dalam mengonsumsi barang dan jasa pada jangka waktu tertentu dan menurunkan daya beli masyarakat. Pertumbuhan yang berkelanjutan harusnya ditopang dengan pengeluaran yang berbasis investasi. Karena penyerapan modal di sektor industri untuk pengadaan barang modal, peningkatan belanja pemerintah akan barang modal, serta perbaikan infrastruktur akan 
membutuhkan tenaga kerja yang dapat mengurangi pengangguran dan meningkatkan output. Belanja pemerintah dapat dilihat pada grafik dibawah ini:

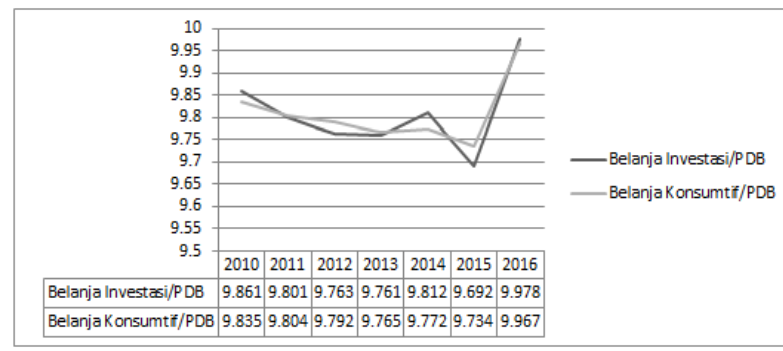

Sumber: Bank Indonesia 2016, Data diolah

\section{Gambar 2.}

Belanja Pemerintah Tahun 2010-2016 (dalam Miliyar Rupiah)

Pengaruh Investasi Terhadap Pertumbuhan

Ekonomi Indonesia dalam Jangka Panjang

Hasil penelitian menunjukkan bahwa investasi berpengaruh negatif terhadap pertumbuhan ekonomi Indonesia tahun 1993-2016. Hal ini dikarenakan koefiesien sebesar -0.236701. Respon negatif ini pertumbuhan ekonomi akibat Gross Fixed Capital Formation ini tidak sesuai dengan pandangan Capital Fundamentalism dalam ekonomi konvensional yang menyatakan bahwa pembentukan modal memerankan peran penting dalam model pertumbuhan ekonomi. Hal ini serupa dengan hasil penelitian yang dilakukan oleh Yuksel dan Zengin (2016) serta Penelitian Muhamed Goaied dan Saefallah Sassi (2010).

Gambar 3 juga menjelaskan hubungan negatif dari GFCF dan pertumbuhan ekonomi. Hal tersebut dapat dilihat pada tahun 2010 ketika Gross Fixed Capital Formation mengalami kenaikan sebesar $48 \%$ pertumbuhan ekonomi Indonesia mengalami penurunan sebesar $1,5 \%$. Penurunan ini terus terjadi hingga tahun 2016 dan membuktikan adanya hubungan negatif antara Gross Fixed Capital Formation dan pertumbuhan ekonomi Indonesia.

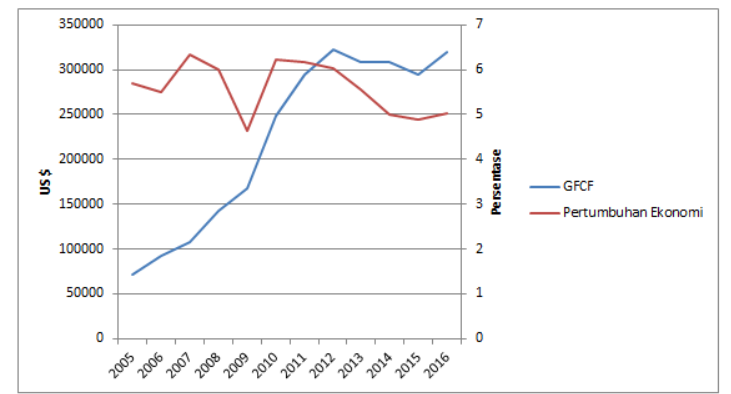

Sumber: World Bank Data, Data Diolah

\section{Gambar 3}

\section{Perbandingan Gross Fixed Capital}

Formation dan Pertumbuhan Ekonomi Indonesia tahun 2005-2016

\section{PENUTUP}

\section{Simpulan}

Berdasarkan hasil analisis dan pembahasan yang telah dilakukan pada bab sebelumnya, maka kesimpulan yang dapat diambil adalah sebagai berikut:

1. Berdasarkan hasil analisis data diatas, menunjukkan bahwa pembiayaan perbankan syariah, dan investasi mamiliki pengaruh jangka pendek terhadap pertumbuhan ekonomi Indonesia tahun 1993-2016. Hasil tersebut menyimpulkan bahwa $\mathrm{H}_{0}$ Berdasarkan hasil analisis data diatas, menunjukkan bahwa pembiayaan perbankan syariah, dan investasi 
memiliki pengaruh jangka panjang terhadap pertumbuhan ekonomi Indonesia tahun 1993-2016.

\section{Saran}

Saran penulis melalui penelitian ini adalah agar pertumbuhan ekonomi Indonesia semakin meningkat seiring dengan meningkatnya total pembiayaan perbankan syariah dan investasi di Indonesia.

\section{DAFTAR PUSTAKA}

Abduh, Muhamad dan Mohd Azmi Omar. 2012. Islamic Banking and Economic Growth: the Indonesian Experience. International Journal of Islamic and Middle Eastern Finance and Management, Vol. 5, No. 1.

Adhikary, Bishnu Kumar. 2011. FDI, Trade Openness, Capital Formation, and Economics Growth in Bangladesh: A Lingkage Analysis. International Journal Of Business and Management, Vol. 6, No. 1.

Adzhani, Rilanda dan Rini. 2017. Komparasi Kinerja Perbankan Syariah di Asia dengan Pendekatan Maqashid Syariah. Jurnal Akuntansi dan Keuangan Islam, Vol. 5, No. 1.

Adzhani, Rilanda dan Rini. 2017. Komparasi Kinerja Perbankan Syariah di Asia dengan Pendekatan Maqashid Syariah. Jurnal Akuntansi dan Keuangan Islam, Vol. 5, No. 1.
Ajijah, Shochrul R, dkk. 2011. Cara Cerdas Menguasai Eviews. Jakarta: Salemba Empat.

Alege, Philip O. dan Henry Okuda. 2014. International Competitiveness and Growth of the Nigerian Economy: A Structural VAR-Based Perspective. Research in Applied Economics, Vol. 6, No. 4.

Alimi, R. Santos. 2014. Ardl Bounds Testing Approach To Cointegration: A Reexamination of Augmented Fisher Hypothesis in an Open Economy. Asian Journal of Economic Modelling. Vol. 2(2): 103114.

Antonio, Muhammad Syafi'i. 2001. Bank Syariah dari Teori ke Praktek. Jakarta: Gema Insani Press.

Arikunto, Suharsimi. 2013. Prosedur Penelitian Suatu Pendekatan Praktik. Jakarta: PT Rineka Cipta.

Azam, et al. 2013. The Role of External Debt in Economic Growth of Indonesia - A Blessing or Burden. World Applied Sciences Journal., Vol. 25, No. 8.

Bank Indonesia. 2005. Laporan Perkembangan Perbankan Syariah 2005. Jakarta: Bank Indonesia.

$2008 . \quad$ Laporan Perekonomian Indonesia 2008. Jakarta: Bank Indonesia. 
$2012 . \quad$ Laporan Perkembangan Perbankan Syariah 2012. Jakarta: Bank Indonesia.

$2014 . \quad$ Laporan Perekonomian Indonesia 2014. Jakarta: Bank Indonesia.

$2016 . \quad$ Laporan

Perekonomian Indonesia 2016. Jakarta: Bank Indonesia.

2016. Metadata. Jakarta: Bank Indonesia.

Bappenas. 2017. Perkembangan Ekonomi Indonesia dan Dunia Triwulan I Tahun 2017. Jakarta: Bappenas.

Digdowiseiso, Kumba. 2009. Education Inequality, Economic Growth, and Income Inequality: Evidence From Indonesia 1996-2005. Munich Personal RePEC Archive MPRS Paper No. 17792 hal 213-219.

Fahrani, Yadzan Gudarzi dan Masood Dastan. 2013. Analysis Of Islamic Banks' Financing and Economic Growth: A Panel Cointegration Approach. International Journal of Islamic and Middle Eastern Finance and Management, Vol. 6, No. 2.

Frensindy, Budi. 2007. Bank Based Vs Market Based. Research International Bulettin

Goaied, Muhamed dan Seifallah Sassi. 2010. Financial Development and Economi Growth in The MENA
Region: What About Islamic BankingDevelopment.International Journal of Economics and Finance, Vol. 7, No. 3

Hachicha, Nejib dan Amine Ben Amar. 2015. Does Islamic Bank Financing Contribute To Economic Growth? The Malaysian Case. International Journal Of Islamic And Middle Eastern Finance and Management, Vol. 8, No. 3

Halwani, R Hendra. 2002. Ekonomi Internasional dan Globalisasi Ekonomi. Jakarta: Ghalia Indonesia.

Huda, Nurul dan Muhammad Heykal. 2010. Lembaga Keuangan Islam, Tinjauan Teoritsi dan Praktis. Jakarta: Kencana.

Hung, F.S., \& Cothren, R. 2002. Credit Market Development and Economic Growth. Journal of Economics and Business, Vol 54(3): 219-237.

Ismail. 2010. Perbankan Syariah. Jakarta: Kencana Prenada Media Group.

Mankiw, N. Gregory. 1999. Makroekonomi. Edisi Keempat. Jakarta: Erlangga.

Noor, Henry Faizal. 2009. Investasi, Pengelolaan Kevangan Bisnis dan Pengembangan Ekonomi Masyarakat. Jakarta: PT Indeks. 
Kanu, Succes Ikechi dan Ozurumba, Benedict Anayochukwu. 2014. Capital Formation and Economics Growth in Nigeria. Global Journal Of Human Social Science: E Economics Vol. 14, No. 4.

Otoritas Jasa Keuangan. 2013. Laporan Perkembangan Keuangan Syariah Tahun 2013. Jakarta: Otoritas Jasa Keuangan.

Raiyandana, Ar. 2016. Analisis Pengaruh Sektor Moneter Terhadap Pertumbuhan Ekonomi di Indonesia Periode 1980-2013. Universitas Airlangga: Skripsi Tidak Diterbitkan.

Rajni, Sasmiharti. 2007. Pengaruh Angkatan Kerja Dan Penanaman Modal Tetap Bruto Terhadap Pendapatan Per Kapita Propinsi di Indonesia. Jurnal Kajian Ekonomi, Vol, 5. No. 2.

Rahmaddi, Rudy. 2011. Exports and Economic Growth in Indonesia: A Causality Approach based on Multi-Variate Error Correction Model. Journal of International Development and Cooperation, Vol. 17, No. 2.

Samuelson, A. Paul dan Nordhaus, D. William. 1992. Ekonomi. Edisi 12 Jilid 2. Jakarta: Erlangga.

Soliu, Adegboya dan Ibrahim, Odusanya. 2014. Empirical Analysis of Trade Openness, Capital Formation, FDI, and Economic Growth: Nigeria Experience. Valley International Journals. Vol. 1 No. 36-50.

Sukirno, Sadono. 2010. Makroekonomi: Teori Pengantar Edisi Ketiga. Jakarta: PT Raja Grasindo Perseda.

Taqwa, Khoirul Zadid. 2017. Analisis Kinerja Intermediasi Sistem Kevangan Syariah (Perbankan Syariah dan Pasar Modal Syariah) terhadap Pertumbuhan Ekonomi Indonesia Tahun 2003:Q1-2015:Q4. Skripsi tidak diterbitkan.

Ugochukwu, Ugwuegbe S dan Chinyere, Uruakpa Peter. 2013 The Impact of Capital Formation on the Growth of Nigeria Economy. Research Journal of Finance and Accounting Vol. 4 No. 9.

Undang-undang Perbankan Syariah. 2008. --- Jakarta: Sinar Grafika.

Undang-undang Perbankan. 2009

--------. Jakarta: Sinar Grafika.

Usman, Rachmadi. 2013. Aspek Hukum Perbankan Syariah di Indonesia. Jakarta: Sinar Grafika.

Waljianah, Riza. 2013. Determinan Tingkat Suku Bunga Pinjaman Perbankan di Indonesia (Periode Juli 2005Desember 2011). Jurnal IImiah.

Yuksel, Serhat dan Sinemis Zengin. 2016. Cusality Relationship Between 
Import, Export, and Growth Rate in

Developing Countries. International

Journal of Commerce and

Finance. Vol. 2 No. 1 b.

Yusof, Rosylin Mohd. dan Mejda Bahlous.

2013. Islamic Banking and
Economic Growth in GCC \& East

Asian Countries A Panel

Cointegration Alaysis. Journal Of Islamic Acounting and Business

Research, Vol. 4, No. 2. 